\title{
Bringing Commodity Chain Analysis Back to its World-Systems Roots: Rediscovering Women's Work and Households
}

\author{
Wilma A. Dunaway \\ Virginia Tech \\ wdunaway $($ vt.edu
}

\begin{abstract}
Globally between 1980 and 2000, women's economic activity rate expanded, narrowing the gender gap in labor force participation. Thus, females now account for one-third or more of the "officially-counted" personnel of export industries (UNICEF 2007), and export agriculture is now feminized (Deere 2005). Today women account for one-third of the manufacturing labor force in developing countries, and females hold more than one-half of the industrial jobs in Asia (Barrientos, Kabeer and Hossain 2004). In much of the global South, females account for a majority of the waged labor force in export agriculture, and they are more heavily concentrated than men in service jobs that provision the supply chains of global production. As a reflection of fewer opportunities for males, women are now less likely to withdraw from the labor force during their childbearing years. In addition, females account for a majority of the income earners in the informal sectors of a majority of global South countries, generate a significant proportion of global commodities through subcontracted work they complete in their households, and provide most of the unpaid family labor needed to support household-based farms and businesses that are dominated by males (United Nations 2003).
\end{abstract}

Keywords: Reproductive labor, scientific gender-bias, feminist methods, household economies, non-waged labor

\section{The Glaring Absence of Women from Commodity Chains}

Despite the centrality of women to global production, the accumulated published work of scholars who have "gendered" commodity or value chain analyses represents less than two percent of the total accumulated research. ${ }^{1}$ Since the $1980 \mathrm{~s}$, commodity chain analysis has developed along three divergent intellectual directions: the radical world-systems approach, the mainstream global commodity chains generated by Gereffi and his associates, and the industry-

1. I spent two years researching the three threads of commodity chain research to identify scholars who have integrated gender, women or households into commodity or value chain analysis (even at minimal levels). Since this is not a massive publication area, I reviewed every article or book that is grounded in any of the three strands of chain analysis. While contemporary scholars might prefer to believe that gender/women are routinely integrated into this field, I found only a small number of authors who gendered commodity/value chain analyses between 1980 and 2012. For example, only 1.6 percent of the works included in the massive publication database as of July 31,2013 of the Global Value Chain website (www.globalvaluechains.org) include gender, women or households in their titles, keywords, or abstracts. For more extensive discussion, see Dunaway (2014): 1-4 and bibliography. 


\section{Journal of World-Systems Research}

centric global value chains (Bair 2009: 7-14). ${ }^{2}$ While there are significant differences among these variants, what they have in common is that a majority of the accumulated research in each of these perspectives has "de-gendered" analyses of global production (Clelland and Dunaway 1995; Dunaway 2001; Dunaway 2014: 1-25). ${ }^{3}$ Throughout the 1980s when commodity chain analysis was emerging as a field of study, feminists drew attention to the ways in which the widening of capitalism in the global South was integrating females into commodity production through non-waged labor mechanisms (e.g., Elson and Pearson 1981) and into export agriculture through paid and unpaid labors (e.g., da Corta and Venkateshwarlu 1999). Feminists provided additional clues in the 1990s that capitalist enterprises in the global South were targeting and expanding female non-waged, casualized, temporary, contract and informal labor mechanisms in both industry and agriculture (e.g., Prugl 1999; Clermont and Aligsakis 1995; Collins 1995). ${ }^{4}$ Even though feminist evidence about the significance of women's work to global production has continued to mount since 2000 (e.g., Beneria 2001; United Nations 2003; Deere 2005; Caraway 2007), gender, women and households have not been represented in a majority of commodity or value chain analyses produced since 1985 . In the second decade of the $21^{\text {st }}$ century, feminists are still alarmed that "the gendered questions at the heart of international political economy continue to be neglected" (Bedford and Rai 2010: 2). ${ }^{5}$

With respect to households, the track record of all three intellectual threads is even worse, for these important structures of the capitalist world-system very rarely make an appearance in commodity chain analyses (Dunaway 2001, 2014: 1-25). When their ground-breaking book was published, Gereffi and Korzeniewicz (1994: 12) admitted that the researchers had failed to assess the linkages between households and commodity chains. As Nicola Yeates (2004: 378) has observed, a majority of analysts "have neither positioned the household as a site of production within commodity chains nor theorized the relationship between household production and the transformation of commodity chains." In her seminal overview of the three scholarly threads of chain analysis, Bair (2009: 14-34) assesses the state of the field by calling attention to three predominant debates that cut across all three approaches. Gendered labor strategies, gender inequality and worker households are absent from those debates. ${ }^{6}$ Subsequently, Bair (2010: 205, 224) called for feminist analyses of the gendered nature of globalized production, indicating that

2. Throughout this essay, the term "commodity chain analysis" is meant to refer cumulatively to the knowledge production of all three of these directions.

3. Indeed, researchers often ignore the gender of workers even when the agricultural or industrial workers they are describing are disproportionately females. I am not the first to notice the gender blindness of commodity chain analysts; see Salzinger (2003), Barrientos, Kabeer and Hossain (2004), and Yeates (2004).

4. There is insufficient space to list a full bibliography of this relevant literature; please contact the author if you need citations.

5. On the feminist side of this problem, numerous investigations of women's work in global production have been published since 1980, but very few of these analyses utilize commodity or value chain analysis.

6. Bair (2009) provides empirical evidence that the vast majority of GCC/GVC analysts ignore gender, women and households. The editor defined her goal to be that of assessing the state of the field, so she did not find gender, women or households evidenced strongly in the cumulative research agendas of the field. In her overview of the state of the field, Bair neither identifies gender or women as an area of GCC/GVC research nor pinpoints any $\mathrm{GCC} / \mathrm{GVC}$ analysts who routinely integrate gender. All the references to women in the index refer to one chapter that provides brief empirical information about female workers but does not employ chain analysis. 
a satisfactory approach will "look to how gender, as a set of context-specific meanings and practices, intersects the structure of global capitalism and its systemic logic of value extraction and capital accumulation."

I have three goals for this article. First, I argue that the radical world-systems roots of commodity chain analysis integrated women and households in ways that subsequent scholarship has not. Second, I explore intellectual sexism as a cause for the gender biases of commodity chain analyses. Third, I examine the false analytical divides that underpin gender-blind commodity chain analysis. Throughout, I offer questions and research exemplars that can provide guideposts to scholars who want to avoid the intellectual pitfalls of gender-biased analysis.

\section{Returning to the Radical Roots of Commodity Chain Analysis}

Commodity chain analysis originated in the world-systems perspective, but the field has largely lost sight of those radical roots. In the words of Jane Collins (2014: 28), I seek to return the field to "a critical and liberatory direction that is distinct from the mechanistic approaches to commodity chain analysis that have gained popularity since the 1990s." Except for a few worldsystems analysts, most commodity chain researchers turn this approach away from the critique of capitalism reflected in the radical roots of this approach. For example, preoccupation with the ways in which capitalists "add value" at various nodes of a product chain is the political and economic antithesis of the labor exploitation, sexism, surplus drain, and surplus extraction that are emphasized by foundational thinkers of the world-systems perspective. While Hopkins and Wallerstein (1977: 127-28) envisioned a commodity chain to be "a network of labor and production processes" as so many chain analysts emphasize, they also stressed that the chain map needs to reflect "the reproduction of the labor forces involved in these productive activities." The chain network was conceived to be grounded in sexism, racism and surplus drains from worker households.

Their concept emphasized (a) intermingling of several forms of waged and non-waged, free and unfree labor; (b) extraction of visible and hidden surpluses from households; (c) gendered and racial exploitation of workers; and, (d) economic devaluation of household-based work, especially that of housewives (Hopkins and Wallerstein 1977, 1986, 1994; Smith et al. 1988; Wallerstein 1995a, 1995b). Hopkins and Wallerstein (1994: 49) focused sharply on the pivotal question that should be asked: "If one thinks of the entire chain as having a total amount of surplus value that has been appropriated, what is the division of this surplus value among the boxes of the chain?" It was obvious to them - in ways that were not pursued by subsequent scholars - that worker households "routinely produce real surplus, which is in fact fed right into the world-economy" (Hopkins and Wallerstein 1977: 60, 68, 100). They argued that commodity chain analysis needs to take into account the surpluses that capitalists derive from two hidden inputs supplied by worker households: (a) the reproduction of labor forces and (b) the provisioning of low-paid waged workers. Consequently, they cautioned scholars to conceptualize a commodity chain in terms of multiple levels of surplus extraction from worker households at every spatial node of its lengthy network. ${ }^{7}$

7. In the 1970 s and 1980 s, world-systems thinkers conceptualized households in the modern world-system. See Review of the Fernand Braudel Center 5(3), 7(2), 8(3), 10(1), available through JSTOR. I have broadened and 


\section{Journal of World-Systems Research}

\section{Sexism in Scientific Practice}

"How is it possible not to notice that commodity chains are gendered?" Immanuel Wallerstein (2014: xii) queries. "There is an incredible amount of foot-dragging and resistance to introducing gender into commodity chain analysis," he insists, even though "gender is itself a principal constitutive feature of the commodity chains." This intellectual anomaly derives from the larger crisis in the capitalist structures of knowledge that Wallerstein (1991) has been warning about for two decades. Broadly, there has been "political, economic and scholarly resistance to incorporating gender into the structures of knowledge" of the modern world-system (Wallerstein 2014). Evelyn Fox Keller (1984: 3-5, 178; 1987: 80) points out that gender biases have shaped the production of scientific theory. Vandana Shiva (1993: 26) argues that Western scientists discard women's questions from their research agendas and reject female knowledge constructions through their "patriarchal logic of exclusion." However, the myth of intellectual objectivity insulates the scientist from social responsibility for dismissing women (Keller 1983: 16).

There is empirical evidence that Wallerstein and these feminist scientists are correct. Bluntly put, men do not study women in either the hard sciences or the social sciences (Woolston 2001). In fact, they often fail to incorporate females into their research questions, even when women are impacted more severely (or differently) by the phenomenon being investigated (Wilson 2012). Because of this gender clustering, research about women is overwhelmingly conducted by females, whose projects face gender discrimination in scholarly prestige and funding allocations (Ferree 2005; Ritchie 2009).

Complexity scientist Isabelle Stengers (1997) is concerned that scholars construct knowledge through a process that authorizes and rewards exclusion of many worthwhile questions. What gets produced as knowledge depends on the consensus reached in scientific communities (Keller and Longino 1996: 274), but their rankings are determined by funding and publishing marketplaces in which a few problems have the greatest value (Stengers 1997: 128). Wallerstein (1995a: 84, 130) is more explicit. He contends that scientists form a fraternal order that protects the interests of the world's accumulators of capital. Thus, pro-capitalist scholars determine "what scientific questions are asked" and "what scientific risks are worth taking." Consequently, the practice of science is grounded in criteria of "value-added" to economic interests. Keller (1982) and Stengers (1997) point to the centrality of the selection process to knowledge production. Choice of theoretical model and research methodology is politically motivated by the training of scientists "to devalue and to scorn" research about questions that are not rewarded by the scientific community. In this way, Stengers $(1997: 74,116)$ says, capitalist science is "imagination in the service of power." Keller argues that scientists adhere to ideological and economic criteria that guide them away from the closed box of gender investigations (Keller and Longino 1996: 252). Thus, capitalist science is "haunted," Stengers (2010, vol. 2: 285, 398) insists, "by the ghosts of those who have [been] reduced to silence or ridicule" by such biased scientific reasoning.

So what can we do to avoid these traps? Stengers (1997: 113) and Keller (1982) advise us to stop giving ourselves permission to ignore research directions that focus on groups or questions that are typically ignored. In this regard, Marxist Daniel Singer (1999: 221-22) argues

revised their conceptualization; see Dunaway (2012, 2014: 55-71). 
that the Left needs to engage in collective introspection about its failures with respect to women. "We men in particular must proceed with a deep self-examination," he says, "to discover the prejudices inherited for generations and the extent to which they condition our behavior." When defining topics of study and research questions, Stengers (1997: 51-52) advises us to ask ourselves: "Who are the "excluded others' whose relevance and significance I am denying?" In simpler terms, I would add that researchers (both male and female) need to ask themselves this question: "If I look out at my subject matter and never see women, why is that?" The answer is very rarely going to be that there are no women there. Intellectual silencing of women is grounded in the same forms of ideological sexism that underpin economic subordination of females and capitalist devaluation of women's work. What are the questions that scholars should explore to overcome such scientific sexism $?^{8}$

1. To what degree do women supply the paid and unpaid labors that are embedded in the commodity chain?

2. How does the commodity chain transform and reshape women's work and household survival?

3. To what degree do surplus extractions from households and women subsidize the production process (through non-waged inputs and labors)?

4. To what degree does the commodity chain externalize material, political, social and ecological costs to households and to women?

5. To what degree do households and women at lower nodes of the commodity chain subsidize households, laborers, or consumers at higher nodes (effecting cheaper prices in distant markets)?

6. To what degree does the commodity chain structure gender inequality and/or sustain patriarchy within and among the households that comprise its entire labor force?

7. To what degree do women and households shape and resist commodity chain structuring and impacts?

\section{The False Analytical Divide between Production and Reproduction}

Degendered commodity chain analyses are grounded in a false analytical divide between production and reproduction. Among the most fundamental challenges to conventional economics and economic history posed by a gender perspective is the importance that one might attach to everyday life," argue Bettio and Verashchagina (2008: 32-34). Preoccupied with "productive" activities as represented by commodified labor and market exchanges, Western economists marginalize the reproductive (Peterson 2003). In this same vein, most commodity chain analysts have treated market/production and household/reproduction as discrete and disconnected spheres. By following that sexist approach, these scholars deny that capitalists

8. For research exemplars that embed these questions into commodity chain analysis, see the articles and the bibliography of Dunaway (2014). 


\section{Journal of World-Systems Research}

benefit greatly from externalization of the costs of reproduction and maintenance of the labor force to households and communities (Wallerstein 1995b).

More than three decades ago, Lourdes Beneria (1979: 216) pointed out that economic change needs to be "analyzed from the perspective of the different effects on the sexes, a dimension that has often been neglected." Analyses should concentrate on two levels, she argued: (a) how the transformation alters the productive and reproductive functions and the gendered division of labor of households and (b) how economic restructuring impacts communities and societies by imposing new conditions under which social reproduction must occur. In line with Beneria's thinking, questions about three types of reproduction are relevant to commodity chain analysts: (a) how unpaid biological reproduction subsidizes the chain, (b) whether the chain threatens or supports household reproduction and maintenance, and (c) whether the chain threatens natural reproduction of affected ecosystems. Marx (1867, vol. 1) suggested a fourth type of reproduction that should concern scholars: the degree to which the chain constructively reproduces (or contributes to structural crises of) the infrastructure and processes of the capitalist world-system.

Mainstream economists recognize that capitalists are only able to keep their prices competitive because they do not have to pay for reproduction (Terleckyj 1975: 230-231). However, economists have dismissed the structural relationship between the production of commodities and social reproduction of the labor force, by treating reproduction artificially as though it is not a factor of production (Mies 1986). Since production and reproduction are far more intertwined than economic theory admits (Terleckyj 1975), there is need for more compelling questions and deeper insights about the ways in which the productive and the reproductive are inextricably linked and overlapping (Clough and Halley 2007). For help with rethinking, we can return to the intellectual roots of the world-systems conceptualization of commodity chains. Hopkins and Wallerstein (1977: 127-28, my emphasis) stressed that the chain mapping needs to reflect "the reproduction of the labor forces involved in these productive activities." In reality, "no production system operates without a reproductive system," and reproductive mechanisms are the "intimate Others" of globalized production systems (Truong 1996: 47).

There are five ways in which reproductive labors are routine elements of commodity chains. First, it is in the reproductive sphere that workers are socialized in the characteristics of a "productive" laborer. Learned skills, such as time management, work ethic, and inter-human relationships, are essential to efficiency, productivity and profitability in the capitalist workplace.

Second, production and reproduction share the same material and social bases, even though theorists artificially separate them. In the neoliberal period, a disproportionate share of fiscal resources has been allocated toward global productive systems, eliminating historical public expenditures for social reproduction (Katz 2001). When production absorbs, pollutes or destroys too many of a society's ecological and social resources, reproductive spheres are threatened. As a result, poverty and hunger have expanded at the same time that global productive systems have created greater wealth than has ever existed in the world (Sehgal 2005). In similar fashion, ecological resources have been disproportionately allocated to (or polluted/wasted by) global productive systems, withdrawing them from reproductive uses. In

9. See Feminist Economics (No. 3, 1996) for a special issue about the links between production and reproduction. 
these two contexts, the reproductive needs of laborers and communities have been "unhinged from production" (Katz 2001) to such an extent that much of the reproductive value of shared material resources is exported away from the people and communities that need them most for survival. Consequently, hunger and malnutrition are common in developing countries that export vast amounts through food commodity chains, and medicines are not applied where they are most needed because people cannot afford them (United Nations 2004). In reaction, households develop extra-market survival strategies to overcome the shortfalls in basic needs caused by productive systems that are no longer synchronized with reproductive systems.

Third, much of the labor required to generate the commodities that fill chains crisscrossing the globe takes non-waged forms that are closely tied to reproductive spheres. Many household activities have been incorporated into markets and commodity chains, including artisan crafts, agricultural crops, fishing and aquaculture. Thus, household members simultaneously complete household tasks and produce for the market, and a researcher cannot easily see where reproductive activities end and productive ones begin. Much of this activity occurs in informal sectors where two-thirds of the people of the global South earn livelihoods. Commodity chains routinely integrate informalized and causalized labor forms with factory production, and much of this work is household-based. Family members, especially females, supply unpaid labor to capitalist enterprises that are based in households (e.g., farms, textile workshops), and these forms of women's work represent a gray zone in which the females themselves do not demarcate boundaries between reproductive and market-oriented activities (United Nations 2003). In this context, a woman's reproductive labors are extended to the capitalist enterprise, as is the case with wives who provide cleaning, food preparation and family networking functions for their husband's export textiles shops or commercial fishing/aquaculture operations (Dedeoglu 2008; Ferolin and Dunaway 2013). When she subcontracts commodity production, the female homeworker further clouds the demarcation between reproduction and production, especially since she draws from her accumulated pantry of reproductive resources and child labor to complete the work for which she will earn income. Typically, most of her work - both productive and reproductive - is rendered invisible from public records and from commodity chain mapping.

Fourth, "the market" has broken down the analytical distinction by commodifying traditional reproductive functions. Monetization of subsistence resources generates household reliance on wages to be used to purchase survival needs from markets. Thus, reproductive resources must be secured from markets supplied by productive systems that generate commodities for exchange (Wallerstein 1995a). Households "move their unpaid reproductive labour into the commodity and services market, earning wages with which to purchase goods and services which replace unpaid domestic service" (Pearson 2000: 223). In addition, markets commodify reproductive functions to such an extent that all forms of domestic work and biological reproduction can be purchased. Hospitals and health care personnel sell health and reproductive services, and women's bodies are controlled by commodities that regulate or prevent reproduction. Even the human conception and birthing process can be profitably replicated through market mechanisms that do not require women (Mies and Shiva 2001: 17495). To complicate matters, the world economy has structured an international division of reproductive labor in which domestic servants, nurses and sex workers migrate from poorer countries to sell their services in richer countries (Yeates 2004). In this global marketing of transnational laborers, the distant consumers shift their reproductive work to transnational 


\section{Journal of World-Systems Research}

migrants. In this way, the costs of social reproduction are externalized to the labor-exporting country, keeping expenses low where most of the benefits accrue (Katz 2001). At this point, the reader should seriously question that there is any clear division between production and reproduction. If the analytical distinction were as great as economic theory suggests, reproductive labors would stay outside the market and not become economically valuable commodities.

Fifth, the contradictory narrow space between reproductive sphere and workplace threatens the efficiency and profitability of productive systems. The burdens of unpaid household labor and childcare deter the entry of females into waged labor and many forms of productive self-employment at exactly the time when commodity chains are targeting such females for lowpaid production. When they do increase their labor force participation and their income-earning activities, "women's increased role in the labour markets of the global economy has not been matched by an increased participation of men in unpaid domestic work" (Pearson 2000: 228). It should be of concern to capitalists seeking cheap female laborers that women spend more time than men on unpaid work. Indeed, women spend 50 to 70 percent as much time as men on paid work, but almost twice as much time as men on unpaid work. On an average day, a woman in the global South will allocate 2.5 hours more than men to reproductive basic needs (United Nations 2003). The murky space between reproductive and productive labors is further confounded by dangerous behaviors that females encounter when they enter the workplace. Who is responsible for the safety of women and girls who face harassment or physical threats on the way to workplaces (Prieto 2009), especially in societies where females are just beginning to enter the public labor force? Why do male workers inappropriately harass female peers for "reproductive" services in workplaces, if the division between the two spheres is so clear?

The operations of commodity chains are not separate or shielded from a mythological sphere to which "the reproductive" or the "gendered" are consigned, so as not to contaminate "the economic." Instead, markets "embody gender hierarchies as they are found in society and its institutions" (UNRISD 2005: 65). Every node of every commodity chain is shaped by the gender and patriarchal relations of its geographical and social space, and the sexual division of labor in households is often replicated in productive nodes of commodity chains. Jennifer Bair (2010: 209) observes that export-oriented production "depends on the intersection of social organization. . . and a set of patriarchal ideologies and practices, which together create a particular opportunity structure for exploiting female labor." Consequently, capitalist labor strategies (especially in the form of lowered remuneration for females) benefit from the gender inequalities and patriarchal constraints that characterize the societies in which production and distribution occur (Werlhof 2007). Because the labor market is segmented by gender, race and ethnicity, women are concentrated into fewer, lower-paying occupations that are characterized by poor working conditions and few prospects for advancement. In short, "there are reasons for caution in equating women's paid work with empowerment" (UNRISD 2005: 68).

\section{The False Analytical Divide between Household and Market}

If we are to engender the commodity chain, we must investigate how and by whom surplus is produced and extracted at every node of a commodity chain. To accomplish this task, we must enter through the doorway of the household. It is beyond this portal that we find the forgotten woman, and we will find her working longer paid and unpaid hours than men, to contribute 
surpluses that do not appear in the account books of the capitalist enterprise or in the government's tally of the Gross National Product. Fernand Braudel (1979: 16, 28-29) argues that we cannot understand the economy unless we investigate how people's everyday lives are intertwined with it. Similarly, feminist economists contend that one of the "most fundamental challenges to conventional economics and economic history posed by a gender perspective is the importance that one might attach to everyday life" that "encompasses the daily tasks of reproduction" situated within households and local communities (Bettio and Verashchagina 2008: 32-34). However, everyday life of workers, their households and their communities has been "the great absentee" from much of economic history (Braudel 1979: 16), from measures of economic growth (Perelman 2011), and from a majority of commodity chain analyses (Raworth 2004).

At the macrostructural level, a commodity chain is the global mechanism that insures the inequitable division of surplus among the core, semiperiphery, and periphery. Long before those expropriations can occur, however, the commodity chain structures the maximal exploitation of under-paid and unpaid labor. If we are to engender the commodity chain, we must investigate how and where surplus is produced by women at every node of the network, for females are the invisible workforce of global commodity networks. However, it is in the analysis of women's work that commodity chain mappings are probably weakest. Conceptually, we need to stop being blinded by over-simplified stereotypes about women being trapped in housebound labors outside the reach of market forces. If we search only for "manifestations of their private roles as housewives and mothers," we miss the "multigridded" nature of women's work (Hansen and Philipson 1990: 139-40), as well as the complex "dialectics of waged and unwaged labor" that characterize most women's resource accumulation (Collins and Gimenez 1988). Finally, we need to move away from the naive and outdated notion that all work done by women in households is without economic value and is outside the market. We need to investigate how women's work is embedded within a gendered division of labor that allocates different tasks and statuses to women and men. It is not enough, however, to search out "women's work" as a distinct category from "men's work." That can only lead us toward silencing and homogenization of much of women's work that is disguised behind class and racial junctures among women. An effective examination will pinpoint women's and men's differential access to and control over material resources, alongside the structural inequalities that exist among females.

Moreover, we must take special care when analyzing the work done inside women's households, for much of that work is aimed at the marketplace (Dunaway 2001). To varying degrees depending on their class and racial positions, women in the global South engage in a complex portfolio of agricultural and nonagricultural labors that are embedded in commodity chains, including: (a) unpaid labors to sustain the household, clan or family; (b) unpaid labors associated with biological reproduction and child rearing; (c) unpaid labors that subsidize household-based male-dominated market farming or businesses; (d) waged or salaried labor in formal documented contexts; (e) waged or salaried labor in informal sectors; (f) production and/or selling of goods or services in the informal sector; (g) business operation inside or outside the household; and, (h) income-earning homework that is subcontracted by exporters. Even though commodity chains exploit numerous visible and concealed female labors, gender inequality and patriarchy have not been broken down by their income earning. Men are more likely to be concentrated in formal, more closely regulated occupations, consigning females to more precarious informal and casual jobs (Barrientos, Kabeer and Hossain 2004). In comparison 


\section{Journal of World-Systems Research}

to men, women are still more likely to experience temporary jobs, lower pay, precarious subcontracting, excessive overtime, denial of rightful benefits, higher unemployment and extreme levels of health risk (UNRISD 2005).

These disparities make it clear that commodity chains structure, preserve and exploit gender inequalities. These chain networks are grounded in sexism, racism and economic devaluation of household-based work, especially that of females (Hopkins and Wallerstein 1977, 1986). In addition to several visible (but undervalued) contributions by females, commodity chain analyses need to take into account the surpluses that capitalists derive from two hidden inputs: (a) the reproduction of labor forces and (b) the household provisioning of low-paid waged workers. We need to envision commodity chains as more than over-simplified material boxes, for every node of a lengthy commodity chain encompasses:

1. multiple levels of surplus extraction from worker households and from women;

2. patriarchal mechanisms that lead to public invisibility and economic devaluation of women's diverse portfolio of labors;

3. several non-material and/or cultural manifestations of the local impacts of globalized production and consumption systems; and,

4. activism and resistance by households and by grassroots organizations.

In addition to these complexities, it is important to recognize that households "add value" to commodity chains. Indeed, households are centers of both productive and reproductive labors that are essential to commodity chains. The linkages that women forge between households and commodity chains are hydralike, shooting out in multiple directions. It is a conceptual mistake to draw an analytical distinction between the household sphere and production, for the household is just as much a capitalist unit of production and reproduction as are the farm, the factory, and the marketplace (Mies 1986). To detect the entire surplus that is generated by and extracted from the workers who produce and move goods within commodity chains, we must examine households where the labor forces of all commodity chains are created and sustained. Furthermore, much of the production of global commodities now occurs within households, not in factories. As feminist scholars have argued for three decades, much of global production is structured within households in both paid forms (e.g., contract piecework) and unpaid forms (e.g., wife's support of a husband's export farming or textiles sweatshop) (Carr, Chen and Tate 2000; United Nations 2003; Dedeoglu 2008).

Thus, scholars need to integrate households because they are now increasingly the sites of activities that feed into (or challenge the continuation of) production systems. Moreover, household laborers often produce supplies and provide services that provision the formal production process (Beneria 2001; United Nations 2003). By the mid-1990s, half the global garment industry workforce consisted of home-based workers who "feed productive profitmaking output from their homes into the more formal manufacturing companies" (UNRISD 2005: 82). At the turn of the $21^{\text {st }}$ century, 70 to 80 percent of these homeworkers are females (United Nations 2003) whose economic inputs have been excluded from national GDPs and from scholarly commodity chain analyses. Peasants comprise about half the population in the global South; they ground their export agriculture, fishing or aquaculture within households, and their reallocation of labor triggers conflicts between household subsistence needs and commodity 
marketing. ${ }^{10}$ More than two-thirds of the population of South Asia, Sub-Saharan Africa and all the least developed countries is still concentrated in rural areas, and this geographical distribution impacts females disproportionately. Women account for a majority of the world's poor, and they are concentrated in rural areas. ${ }^{11}$ While 70 percent of the world's poor reside in rural areas, 60 percent of the world's land is urbanized. Even though they produce half the world food supply, women own only 1 percent of world land. ${ }^{12}$ Women are over-represented in the rural populations of much of Africa and Asia because males migrate to find employment (Alvarez and Stloukal 2008), and females provide a majority of the paid and unpaid agricultural labor in all regions of the world (United Nations 2003). To complicate matters, peasant debt bondage supports export production while endangering household reproduction (Ferolin and Dunaway 2013).

Households provide a second significant service that "adds value" to commodity chains. Capitalists maximize profits by externalizing costs of production to households (e.g., costs assumed by home-based contract workers) and to the ecosystems that provision them. In addition to shifting costs of laborer reproduction to households, capitalists externalize many of the real costs of commodity production to households, communities and ecosystems. These externalized costs are not unusual or extraordinary, for they are "part and parcel of normal capitalism, and they are to be found at every node/link of every commodity chain" (Wallerstein 1995b). Within a commodity chain, externalities serve three critical functions. Capitalists are more competitive when they keep labor costs low by externalizing costs to households, and they maximize profittaking through externalized costs that lower consumer prices. Hidden labor and inputs that are unpaid or acquired at below global market value provide the capitalist a "degree of monopoly" in relation to competitors (Clelland 2014). However, these externalized costs place social reproduction at risk in much of the world, as ecological resources, foods and public funding are captured by export chains (Sehgal 2005).

There is a third way in which households are crucial to capitalism, for they are the structural end points of commodity chains. Without households, consumer goods would have far fewer arenas for marketing and profit-taking. Disproportionately, women collect and process the capitalist goods (and dispose of the associated waste) that are utilized by households. "In the modern world-economy the organization and composition of households embodies the construction of consumption" (Gereffi and Korzeniewicz 1994: 12). However, consumption is no more gender neutral than production of a commodity. Key transnational corporations control the development and distribution of new consumer goods and define the spatialities and target groups that will be the markets for commodities. Consequently, consumption is structured around and reinforces gender inequalities, as well as the polarization between rich and poor countries. Men and women do not equitably consume commodities, and there are significant disparities in consumption by females of different national, racial, ethnic and class positions. Global South workers do not just produce commodities for others to use, for they actively seek to be consumers in ways that conflict with existing gendered institutions (Ramamurthy 2003).

10. The transition to urbanization is not occurring very rapidly in a great number of countries. In 54 countries, twothirds of the population is rural while 50-61 percent of the population is rural in another 26 countries. See www.nationmaster.com/graph/peo per_liv in_rur are-people-percentage-living-rural-areas.

11. See http://data. worldbank.org/indicator/SP.RUR.TOTL/countries/1W?display=default

12. http://www trickleup.org/poverty/women.cfm?gclid=COeMpKatwrwCFUcV7AodRS4ALw 


\section{Journal of World-Systems Research}

Increasingly, poor households in the global South are targeted to be the "new markets" for imported consumer goods. Consumption of modern commodities leads to alteration of traditional labor strategies and to cultural norms, and these changes are gendered in impacts on households. Dialectically, consumption stimulates change in such a way that gendered inequalities can be minimally altered while patriarchy is reconsolidated (Werlhof 2007). Consumption of cheap goods can simultaneously "improve" the living conditions of worker households and threaten household survival labor strategies and resources. Metaphorically, then, consumer goods are simultaneously "the good, the bad, and the ugly" in their impacts on households.

Finally, households are key institutions within commodity chains because they form spatialities of resistance. Households can threaten productivity and profits within commodity chains, for they often are the locations for nurturing and educating laborer activism and resistance, most especially in contexts in which public meeting places are limited and government or employer repression is high. Especially during economic downturns, households are loci of antisystemic resistance. Workers resist the "lean" policies within production systems to try to insure that waged employment "is remunerated minimally at the level of household reproduction" (Wallerstein 1995b: 1). In addition, householders challenge the commodification of their provisioning resources and of their informal sector production. Historically, peasants and indigenous peoples have resisted when their ancestral lands have been threatened by capitalist encroachment. Social movements resist decline in livelihoods caused by capitalist expansion and press for land reforms when natural resources become concentrated into the hands of agrarian capitalists. Women's activism is often organized within households where they combine incomeearning with resistance and employ household resources to mobilize their movements (Mills 2005; Agosin 2008).

Is bringing in households and women an impossible task? No, it is not! The inputs of women and households into commodity chains are publicly visible (though often not officially counted), and they are being increasingly documented by states and by international development agencies. Females now constitute a majority of the workforces in global South areas of capitalist expansion, and those females typically suffer greater degrees of income inequality, poverty, malnutrition and health problems than their male counterparts (Selwyn 2012: 108-126). In addition, a high proportion of commodity chains structure putting out and subcontracting systems that require productive labors to be undertaken within households (Barrientos 2011). Moreover, it is not impossible to quantify unpaid, non-waged and informal sector labor. Since the 1920s, some mainstream American economists, including Nobel Laureate Simon Kuznets (1941, vol. 1: 10), have argued that several forms of unpaid household labor need to be taken into account in measures of economic growth and GDP. Moreover, the contribution of household labor to economic growth is routinely covered in undergraduate textbooks (Perelman 2011: 200-212).

For two decades, mainstream international organizations have been prioritizing research about these undocumented labors and about the linkages between households, gender and commodity production. In the $1990 \mathrm{~s}$, the United Nations and the World Bank began to fund national time use surveys to quantify unpaid household labor (Clermont and Aligisakis 1995). ${ }^{13}$

13. Since the 1970 s, feminist scholars have measured the time inequalities in the allocation of unpaid household labors (Antonopoulos and Hirway 2010) and proposed approaches for integrating the value of unpaid household labors into national GDP (e.g., Beneria 1992; Himmelwitt 2002; Luitzel 2005). 
As a result, 23 global South countries and two Western nations now report an economic value for unpaid household labors within their GDP. The United Nations Statistics Division (2011) recently published guidelines for integrating unpaid work into national accounting procedures. A current United Nations project focuses on the "political and social economy of care" in order to articulate this unpaid household labor "with the commodity economy" (Budlender 2007). Similarly, the World Bank has encouraged global South countries to develop methods for documenting the economic value of their informal sectors. Since 1995, the Bank has fostered more than 5,000 working papers about statistical approaches to measure the informal sector, and Bank databases include a wide array of statistical information for most global South countries. ${ }^{14}$ In addition, private scholarly projects have developed strategies for measuring time allocation in households of the global South (cf. Antonopoulos and Hirway 2010).

\section{The False Analytical Divide between Informal Sectors and Commodity Chains}

Most commodity chain analysts practice their art as though there is a sharp divide between "formal" labor and inputs and the informal sector. Consequently, these investigators treat informal inputs into global commodity chains as though they never occur. However, the $21^{\text {st }}$ century world-economy is stimulating fewer formal waged workers than informal sector livelihoods. Informal sectors absorb the vast majority of workers in the global South, and women are more concentrated in these jobs than males. As a result, most of the workers in commodity chains are off the books and hidden, and capitalists prefer it this way because it allows them to keep production costs lean, consumer prices low, and profit margins wider. ${ }^{15}$ Every commodity chain that originates in the global South is supported by thousands of laborer households, but these workers and their families acquire only a minority of their survival needs from formal wages in capitalist sectors. On average, a single multinational corporation does not employ enough waged or salaried workers to account for more than one percent of the total available labor force in a global South country (UNRISD 2005). To conceptualize the full role of reproductive labors and households in commodity chains, scholars must assess the extent to which capitalists derive labor, inputs and services from the informal sector, where women are concentrated.

Rather than adapting a form of commodity chain analysis that only describes the easily discerned waged workers and a few managers, scholars need to assess the ingenuity of capitalists at using household-based informal sector goods and services, subcontracting and outsourcing, as well as informalized workers on their productive sites (UNRISD 2005). Such informal labor is an historical and a contemporary feature of capitalism that is much more common than waged labor (Tabak and Crichlow 2000). Consequently, such "non-waged labor is a condition of - and not coincidental to - the so-called productive economy" (Peterson 2003: 14). For that reason, commodity chain analysts who ignore such workers will describe only a small proportion of the

14. A search of the Bank website calls up 486 projects funded since 2000 to develop a model that can be used in the Global South to define and quantify the informal sector.

15. The term "off the books" is not meant to imply that all these workers are fully undocumented or that it is extremely difficult for researchers to locate and to observe their labors as part of commodity chains. 


\section{Journal of World-Systems Research}

productive laborers and will have a misunderstanding of the degree to which the formal sector is dependent upon the informal sphere.

\section{Looking to the Future}

It is intellectually short-sighted to continue to ignore gender, women and households in the analysis of commodity chains. Even though it has been inadequately applied in this way, commodity chain analysis can be utilized to reveal the multiple forms of exploitation of women's work that are embedded in globalized products. For that reason, the commodity chain concept is one of the most promising tools through which world-systems analysis can be translated into activist praxis. If we return to the radical world-systems roots of commodity chain analysis, we will "recover some of what neoclassical economics makes us forget: living, breathing, gendered and raced bodies working under social relations that exploit them" (Collins 2014: 27). Because commodities are "containers of hidden relationships" (Willis 1991: 52), we need to demystify them in order "to uncover in whose interests and in what ways realities are hidden, and then justified as normal, as inevitable" (Wallerstein 2014). This is the goal that commodity chain analysis needs to seek to achieve.

\section{References}

Antonopoulos, Rania, and Indira Hirway, eds. 2010. Unpaid Work and the Economy: Gender, Time-Use and Poverty in Developing Countries. New York: Palgrave Macmillan.

Agosin, Marjorie. 2008. Tapestries of Hope, Threads of Love: The Arpillera Movement in Chile. Lanham, MD: Rowman and Littlefield.

Alvarez, Gustavo and Libor Stloukal. 2008. "Rural Population Change in Developing Countries: Lessons for Policy Making." Geneva: Food and Agriculture Organization: ESA Working Paper No. 08-09.

Bair, Jennifer. 2010. "On Difference and Capital: Gender and the Globalization of Production." Signs 36(1):203-226. . ed. 2009. Frontiers of Commodity Chain Research. Stanford: Stanford University Press.

Barrientos, Stephanie. 2011. "Labour Chains: Analysing the Role of Labour Contractors in Global Production Networks." Brooks World Poverty Institute, Working Paper 153, www.manchester.ac.uk/bwpi.

Barrientos, Stephanie, Naila Kabeer, and Naomi Hossain. 2004. "The Gender Dimension of the Globalization of Production." Geneva: International Labor Organization, Working Paper 17.

Bedford, Kate and Shirin Rai. 2010. "Feminists Theorize International Political Economy." Signs 36(1):1-10.

Beneria, Lourdes. 1979. "Reproduction, Production and the Sexual Division of Labour." Cambridge Journal of Economics 3:203-225.

1992. "Accounting for Women's Work: The Progress of Two Decades." World Development 20(11):1547-1560. 
2001. "Shifting the Risk: New Employment Patterns, Informalization and Women's Work." International Journal of Politics, Culture, and Society 15(1):27-53.

Bettio, Francesca and Alina Verashchagina, eds. 2008. Frontiers in the Economics of Gender. London: Routledge.

Braudel, Fernand. 1979. Afterthoughts on Material Civilization and Capitalism. Translated by Patricia Ranum. Baltimore: Johns Hopkins University Press.

Budlender, Debbie. 2007. "A Critical Review of Selected Time Use Surveys." Geneva: UNRISD Online.

Caraway, Teri. 2007. Assembling Women: The Feminization of Global Manufacturing. Ithaca, NY: Cornell University Press.

Carr, Marilyn, Martha Chen, and Jane Tate. 2000. "Globalization and Home-Based Workers." Feminist Economics 6(3):123-142.

Clelland, Donald. 2014. "Unpaid Labor as Dark Value in Global Commodity Chains." Pp. 72-89 in Gendered Commodity Chains: Seeing Women's Work and Households in Global Production, edited by W. Dunaway. Stanford: Stanford University Press.

Clelland, Donald, and Wilma Dunaway. 1995. "Book Review: Commodity Chains and Global Capitalism." Journal of World-Systems Research 1(1).

Clermont, Luisella, and Elisabetta Pagnossin. 1995. "Measures of Unrecorded Economic Activities in Fourteen Countries." UNDP Occasional Paper 20.

Clough, Patricia, and Jean Halley, eds. 2007. The Affective Turn: Theorizing the Social. Durham, NC: Duke University Press.

Collins, Jane. 1995. "Gender and Cheap Labor in Agriculture." Pp. 217-232 in Food and Agrarian Orders in the World-Economy, edited by P. McMichael. Westport, CT: Greenwood Press.

. 2014. "A Feminist Approach to Overcoming the Closed Boxes of the Commodity Chain." Pp. 27-37 in Gendered Commodity Chains: Seeing Women's Work and Households in Global Production, edited by W. Dunaway. Stanford: Stanford University Press.

Collins, Jane, and Martha Gimenez, eds. 1988. Work without Wages: Domestic Labor and SelfEmployment within Capitalism. Albany, N.Y.: State University of New York Press.

Da Corta, Lucia, and Davuluri Venkateshwarlu. 1999. "Unfree Relations and the Feminization of Agricultural Labor in Andhra Pradesh, 1970-1995." Pp. 71-140 in Rural Labour Relations in India, edited by T. Byres, K. Kapadia, and J. Lerche. London: Frank Cass.

Dedeoglu, Saniye. 2008. Women Workers in Turkey: Global Industrial Production in Istanbul. London: IB Tauris.

Deere, Carmen. 2005. "The Feminization of Agriculture? Economic Restructuring in Rural Latin America." Geneva: UNRISD, Occasional Paper 1.

Dunaway, Wilma A. 2001. "The Double Register of History: Situating the Forgotten Woman and Her Household in Capitalist Commodity Chains." Journal of World-Systems Research 7(1):2-29.

. 2012. "The Semiproletarian Household over the Longue Durée of the Modern WorldSystem." Pp. 97-136 in The Longue Durée and World-Systems Analysis, edited by R. Lee. Albany, NY: State University of New York Press. ed. 2014. Gendered Commodity Chains: Seeing Women's Work and Households in Global Production. Stanford: Stanford University Press. 
79 Journal of World-Systems Research

Elson, Diane and Ruth Pearson. 1981. "Nimble Fingers Make Cheap Workers: An Analysis of Women's Employment in Third World Export Manufacturing." Feminist Review 7(1):87-107.

Ferolin, Maria C. and Wilma A. Dunaway. 2013. "Globalized Fisheries, Depeasantization and Debt Bondage in Philippine Seafood Exporting." International Journal of Humanities and Social Sciences 3(13).

Ferree, Myra. 2005. "It's Time to Mainstream Research on Gender." Chronicle of Higher Education (August 12), 33.

Gereffi, Gary and Miguel Korzeniewicz, eds. 1994. Commodity Chains and Global Capitalism. Westport, CT: Greenwood Press.

Hansen, Karen V. and Ilene J. Philipson, eds. 1990. Women, Class and the Feminist Imagination: A Socialist-Feminist Reader. Philadelphia: Temple University Press.

Himmelwitt, Susan. 2002. "Making Visible the Hidden Economy: the Case for Gender-impact Analysis of Economic Policy." Feminist Economics 8(1):49-70.

Hopkins, Terence and Immanuel Wallerstein. 1977. "Patterns of Development of the Modern World-System." Review 1(2):11-145.

. 1986. "Commodity Chains in the World Economy Prior to 1800." Review 10(1):157170.

. 1994. "Conclusions about Commodity Chains." Pp. 48-50 in Commodity Chains and Global Capitalism, edited by G. Gereffi and M. Korzeniewicz. Westport: Praeger.

Katz, Cindi. 2001."Vagabond Capitalism and the Necessity of Social Reproduction." Antipode 33(4):708-727.

Keller, Evelyn. 1982. "Feminism and Science." Signs 7(3):589-602. . 1983. "Feminism as an Analytic Tool for the Study of Science." Academe 69(5):15-21. 1984. Reflections on Gender and Science. New Haven: Yale University Press. 1987. "Women Scientists and Feminist Critics of Science." Daedalus 116(4):77-91.

Keller, Evelyn and Helen Longino, eds. 1996. Feminism and Science. New York: Oxford University Press.

Kuznets, Simon. 1941. National Income and Its Composition, 1919-1935. Washington, DC: National Bureau of Economic Research, 2 vols.

Luitzel, Heinrich. 2005. "Household Production and National Accounts." Paper submitted to the Second ECE/INSTRAW Joint Meeting. Geneva: UNRISD Online.

Marx, Karl. 1867. Capital: A Critique of Political Economy. London: Penguin Books, 3 vols.

Mies, Maria. 1986. Patriarchy and Accumulation on a World Scale: Women in the International Division of Labor. London: Zed Books.

Mies, Maria and Vandana Shiva. 2001. Ecofeminism. London: Zed Books.

Mills, Mary. 2005. "From Nimble Fingers to Raised Fists: Women and Labor Activism in Globalizing Thailand." Signs 31(4):117-144.

Pearson, Ruth. 2000. "All Change? Men, Women and Reproductive Work in the Global Economy." European Journal of Development Research 12(2):219-237.

Perelman, Michael. 2011. The Invisible Handcuffs of Capitalism: How Market Tyranny Stifles the Economy by Stunting Workers. New York: Monthly Review Press.

Peterson, V. Spike. 2003. A Critical Rewriting of Global Political Economy: Integrating Reproductive, Productive and Virtual Economies. London: Routledge. 
Prieto, Marina. 2009. "Women Workers, Industrialisation, Global Supply Chains and Corporate Codes of Conduct." Journal of Business Ethics 83(1):5-17.

Prugl, Elisabeth. 1999. The Global Construction of Gender: Home-Based Work in the Political Economy of the 20th Century. New York: Columbia University Press.

Ramamurthy, Priti. 2003. "Material Consumers, Fabricating Subjects: Perplexity, Global Discourses, and Transnational Feminist Research Practices." Cultural Anthropology 18(4):524-550.

Raworth, Kate. 2004. "Trading Away Our Rights: Women Working in Global Supply Chains." Oxfam Policy and Practice: Private Sector 1(1):1-52.

Ritchie, Timothy. 2009. "Gender Biases in Research." in Encyclopedia of Gender and Society, edited by J. O'Brien. Thousand Oaks, CA: Sage.

Salinger, Leslie. 2003. Genders in Production: Making Workers in Mexico's Global Factories. Berkeley: University of California Press.

Sehgal, Rakhi. 2005. "Social Reproduction of Third World Labour in the Era of Globalisation." Economic and Political Weekly 40(22):2286-2288.

Selwyn, Ben. 2012. Workers, State and Development in Brazil: Powers of Labour, Chains of Value. Manchester, UK: Manchester University Press.

Shiva, Vandana. 1993. Monocultures of the Mind: Biodiversity, Biotechnology and Agriculture. London: Zed.

Singer, Daniel. 1999. Whose Millennium? Theirs or Ours? New York: Monthly Review Press.

Smith, Joan, Jane Collins, Terence K. Hopkins, and Akbar Muhammad, eds. 1988. Racism, Sexism, and the World-System. Westport, CT: Greenwood Press.

Stengers, Isabelle. 1997. Power and Invention: Situating Science. Minneapolis: University of Minnesota Press. 2010. Cosmopolitics. Minneapolis: University of Minnesota Press, 2 vols.

Tabak, Faruk, and Michaeline A. Crichlow, eds. 2000. Informalization: Process and Structure. Baltimore: Johns Hopkins University Press.

Terleckyj, Nestor. 1975. Household Production and Consumption. New York: National Bureau of Economic Research.

Truong, Thanh-Dam. 1996. "Gender, International Migration, and Social Reproduction: Implications for Theory, Policy, Research and Networking." Asian and Pacific Migration Journal 5(1):27-52.

UNICEF. 2007. Women and Children: The Double Dividend of Gender Equality. New York: UNICEF.

United Nations. 2003. The World's Women 2000: Trends and Statistics. New York: Oxford University Press. .2004. Human Development Report. New York: Oxford University Press.

United Nations Statistics Division. 2011. Guidebook on Integrating Unpaid Work into National Policies. At: www.unescap.org/stat/meet/wipuw/unpaid guide.asp .

UNRISD 2005. Gender Equality: Striving for Justice in an Unequal World. Geneva: United Nations.

Wallerstein, Immanuel. 1991. Unthinking Social Science: The Limits of $19^{\text {th }}$ Century Paradigms. London: Basil Blackwell. . 1995a. Historical Capitalism with Capitalist Civilization. London: Verso. 
81 Journal of World-Systems Research

. 1995b. "The Modern World System and Evolution." Journal of World-Systems Research 1(19).

. 2014. "Foreword." Pp. xi-xiii in Gendered Commodity Chains: Seeing Women's Work and Households in Global Production, edited by W. Dunaway. Stanford: Stanford University Press.

Werlhof, Claudia von. 2007. "No Critique of Capitalism without a Critique of Patriarchy! Why the Left Is No Alternative." Capitalism Nature Socialism 18(1):13-27.

Willis, Susan. 1991. A Primer for Everyday Life. New York: Routledge.

Wilson, Robin. 2012. "Scholarly Publishing's Gender Gap." Chronicle of Higher Education (22 October).

Woolston, Chris. 2001. "The Gender Gap in Science." Chronicle of Higher Education (22 October).

Yeates, Nicola. 2004. "Global Care Chains: Critical Reflections and Lines of Enquiry." International Feminist Journal of Politics 6(3):369-391. 